\title{
Modified analytical model for prediction of steam flood performance
}

\author{
Ankit Dutt $\cdot$ Ajay Mandal
}

Received: 22 March 2012/Accepted: 7 July 2012/Published online: 8 August 2012

(C) The Author(s) 2012. This article is published with open access at Springerlink.com

\begin{abstract}
Steam flooding as a tertiary recovery method for recovery of oil from heavy oil reservoir has been of interest in recent years. Analytical models are very useful to predict oil recovery by steam flooding for preliminary forecasting purposes and sensitivity studies. Though different models are available, the predicted values did not satisfy the field value because of presumptions. In the present study, an attempt has been made to modify the existing Jeff Jones model and Chandra and Mamora model by considering the true profile of steam zone size in reservoir and vertical sweep efficiency for calculation of capture efficiency. The reservoir characteristics and production data of three oil fields, viz., Schoonebeek in the eastern part of Netherlands, San Ardo in Monterey County, California, USA and Hamaca in Venezuela's Orinoco heavy oil belt were analyzed for performance prediction of oil production. The modified model gave very satisfactory results for production performance, compared to the original Jeff Jones and Chandra and Mamora model.
\end{abstract}

Keywords Enhanced oil recovery $\cdot$ Steam flooding · Analytical model · Oil recovery · Production performance

\section{List of abbreviations}

$\Delta S_{\mathrm{o}} \quad$ Change in oil saturation before/after steam front passage (fraction)

$\Delta T_{\mathrm{s}} \quad$ Temperature difference $=T_{\mathrm{f}}-T_{\mathrm{s}}$

$\Phi \quad$ Porosity, percent

$\mu_{\mathrm{o}} \quad$ Average viscosity

A. Dutt · A. Mandal $(\bowtie)$

Department of Petroleum Engineering, Indian School of Mines, Dhanbad 826004, India

e-mail: mandal_ajay@hotmail.com $\mu_{\mathrm{oi}} \quad$ Initial reservoir oil viscosity (cp)

$\rho_{\mathrm{w}} \quad$ Water density (lb/cu ft)

A Effective pattern area (acres)

$A_{\mathrm{s}} \quad$ Steam zone size (acres)

$C_{\mathrm{w}} \quad$ Specific heat of water (Btu/lbm-oF)

D The thermal diffusivity in the overburden and in the reservoir beneath the steam zone $\left(\mathrm{ft}_{2} /\right.$ day)

$E_{\mathrm{hs}} \quad$ Average thermal efficiency of steam zone, dimensionless

$f_{\mathrm{sn}} \quad$ Bottomhole injection steam quality, dimensonless

$F_{\mathrm{hD}} \quad$ Ratio of enthalpy of vaporization to liquid enthalpy, dimensionless

$F_{\text {os }} \quad$ Cumulative ratio of oil displaced from steam zone to water injected as steam, dimensionless

$h_{\mathrm{fg}} \quad$ Latent heat of steam (BTU/lbm)

$h_{\mathrm{n}} \quad$ Net zone thickness (ft)

$h_{\text {st }} \quad$ Steam zone thickness (ft)

$h_{\mathrm{t}} \quad$ Gross formation thickness (ft)

$i_{\mathrm{S}} \quad$ Steam injection rate, cold water equivalent (B/D)

$k_{\mathrm{h}} \quad$ Bulk thermal conductivity of cap rock and base rock (BTU/ft-hr-oF)

$M_{1} \quad$ Average heat capacity of steam zone (BTU/cu ft- ${ }^{\circ} \mathrm{F}$ )

$M_{2} \quad$ Average heat capacity of cap rock and base rock (BTU/cu ft-oF)

$N \quad$ Oil originally in place (STB)

$N_{\mathrm{c}} \quad$ Ratio of the volume of moveable oil to that of steam injection up to the critical time, $t_{\mathrm{c}}$

$N_{\mathrm{D}} \quad$ Cumulative oil displacement (RB)

$Q_{\text {inj }} \quad$ Heat injection rate (BTU/h)

$Q_{\text {s }} \quad$ Rate at which energy is delivered to the steam zone by condensation before breakthrough

$q_{\text {od }} \quad$ Oil displacement rate/Myhill-Stegemeier's oil production rate $(\mathrm{RB} / \mathrm{D})$

$S_{\mathrm{g}} \quad$ Gas saturation (fraction) 
$S_{\text {oi }} \quad$ Initial oil saturation (fraction)

$S_{\text {or }} \quad$ Residual oil saturation (fraction)

$S_{\mathrm{wc}} \quad$ Connate water saturation (fraction)

$t_{\mathrm{c}} \quad$ Critical time (years)

$t_{\mathrm{cD}} \quad$ Time of steam injection at onset of convective heat transport through condensation front, dimensionless

$t_{\mathrm{D}} \quad$ Time of steam injection, dimensionless

$V_{\mathrm{s}, \text { inj }} \quad$ Cumulative steam injection (RB)

\section{Introduction}

Steam flooding is a major EOR process applied to heavy oil reservoirs (Alajmi 2011). As the world is moving toward a depletion era, EOR is required in every field. The demand for energy has been increasing day by day, while the conventional oil reserves are shrinking speedily. In this scenario, heavy oil reserves have become a good source of energy and can fulfill oil demand for a long time in the future. All over the world, billions of barrels of heavy oil and tar sand which cannot be produced by conventional techniques have been reserved. To recover heavy oil, many EOR techniques (Thermal Method, Chemical flooding etc.) are used, of which the thermal method is widely used presently.

Three processes have been evolved in the thermal method: cyclic steam stimulation, steam flooding and in situ combustion. In cyclic steam stimulation, steam is injected into a production well for a period of 2-4 weeks. The well is shut and allowed to soak before re-starting production. The initial production is high because of reduced viscosity at the increased temperature. In steam flooding, steam is injected from the injection well and simultaneously production takes place from the production well. In situ combustion is a displacement process in which an oxygen-containing gas is injected into a reservoir where it reacts with the crude oil to create a high-temperature combustion front that is propagated through the reservoir. In most cases, the injected gas is air.

The present study is concerned with steam flooding. In steam flooding, as the steam zone grows, more oil moves from the steam zone to the unheated zone ahead of the steam front. The oil gets accumulated to form an oil bank. The condensed hot water also moves across the steam front, heating and displacing the accumulated oil. The heated oil with reduced viscosity moves toward the producing well and is produced usually by artificial lifting. There are many factors that promote high displacement efficiency of a steam drive. Firstly, there is expansion of oil and reduction in oil viscosity with temperature (Willman et al. 1961). Secondly, steam distillation of oil left behind the hot water flood increases the overall oil recovery. When a vapor phase (steam) is in the presence of two immiscible liquids (oil and water), each liquid phase exerts its own vapor phase at the temperature of the system. Distillation begins when the sum of the vapor phase (oil and water) equals the total pressure on the system. As a result, oil starts distilling at a temperature much lower than the normal boiling point of its constituents. Thirdly, miscible displacement of residual oil takes place due to the solvent extraction process (Volek and Pryor 1972): Steam distillation strips the more volatile component from residual oil. Steam, enriched with these hydrocarbons, flows through the steam zone and gets condensed at the condensation front. The condensed hydrocarbon contains lighter constituents than the oil resident in that region and can displace some of the oil miscibly. Finally, steam drive is inherently more stable than hot water floods (Prats 1982).

A steam flood project typically proceeds through four phases of development: (1) reservoir screening; (2) pilot tests; (3) field-wide implementation; and (4) reservoir management. Performance prediction is essential to provide information for proper execution of each of these development phases. Three different mathematical models (statistical, numerical and analytical models) are commonly used to predict steam flood performance. The analytical models (volumetric) generally require the entering of few, but critical data. Since, it is much faster to obtain results from analytical models than from simulation, analytical model are still useful tools for preliminary forecasting purposes and sensitivity studies. In addition, the models provide a better insight than simulation into the physics of the thermal process. The economic feasibility of any steam flooding project depends on the accuracy of the predicted production data proposed by the model. One of the most widely used analytical models is the Jeff Jones model. Later Chandra and Mamora (2005) tried to improve this aspect and presented a new analytical model. The objective of this study is focused on improving this aspect of the Jeff Jones model and Chandra and Mamora model. The results of the modified model are tested against results based on field performance for steam drive to verify its accuracy and validity. A more accurate steam flood model will provide engineers with an improved and useful tool for prediction of steam flood production performance. This new model will help to decide the economical feasibility of the project and will help to estimate the total production throughout its economic life.

\section{Theory}

Jeff Jones model

Jones (1981) developed an analytical model to calculate the oil production rate during steam flooding, based on the 
works of Myhill and Stegemeier (1978) and Lookeren (1977). Jeff Jones' steam flood model is divided into two different parts. The first part of the model calculates an optimal steam injection rate (Eq. 1). The second part uses the related data calculated in the first part in conjunction with additional inputs to predict the oil production history (Eq. 4). Jeff Jones modified Myhill-Stegemeier's (Myhill and Stegemeier 1978) oil displacement rate and converted it into oil production rate based on correlation with 14 different steam flood projects.

\section{First part}

$q_{\mathrm{od}}=\frac{N_{\mathrm{dn}}-N_{\mathrm{dn}-1}}{\Delta t}$

where, $\quad N_{\mathrm{d}}=F_{\mathrm{os}} V_{\mathrm{s}, \mathrm{inj}}$

$F_{\mathrm{os}}=\frac{\rho_{\mathrm{w}} C_{\mathrm{w}} h_{\mathrm{n}}}{M_{1} h_{\mathrm{t}}} \Delta S_{\mathrm{o}} \phi\left(1+F_{\mathrm{hd}}\right) E_{\mathrm{hs}}$.

\section{Second part}

Capture efficiency $($ sweep efficiency $)=A_{\mathrm{cD}} \times V_{\mathrm{oD}} \times V_{\mathrm{pD}}$

$A_{\mathrm{cD}}=$ dimensionless area (area sweep efficiency)

$V_{\mathrm{oD}}=$ volume of displaced oil produced, fraction (volumetric displacement efficiency)

$V_{\mathrm{pD}}=$ initial pore void filled with steam as water

$q_{0}=q_{0} \times$ capture efficeience.

\section{Chandra and Mamora model}

Chandra and Mamora presented an improved model of Jeff Jones seam flood analytical model. $\mathrm{A}_{\mathrm{cD}}$ (Eqs. 5, 6) was modified to account for the decrease in oil viscosity during steam flood and its dependence on the steam injection rate. $V_{\mathrm{oD}}$ (Eqs. 7-10) was modified from its square-root format to an exponential form. The third component, $V_{\mathrm{pd}}$ (Eq. 11), was kept unchanged. The oil production profile was divided into three stages as shown in Fig. 1.

$A_{\mathrm{cD}}=\left[\frac{A_{\mathrm{s}}}{A\left\{\alpha \ln \left(\mu_{\mathrm{oi}} / 100\right)\right\}^{1 / 2}}\right]^{2}$

$\alpha=0.00015 i_{\mathrm{s}}+0.05$

Limit: $0 \leq A_{\mathrm{cD}} \leq 1.0$ and $A_{\mathrm{cD}}=1.0$ at $\mu_{0} \leq 100 \mathrm{cp}$

$V_{\mathrm{oD}}=A_{\mathrm{cD} \max }\left[e^{\left\{-\beta\left(\frac{N_{\mathrm{d}}-N_{\mathrm{dmax}} S_{\mathrm{Oi}}}{N \Delta S_{\mathrm{S}}}\right)\right\}}\right]$

$\beta=17.93 N_{\mathrm{c}}+1.3401$

$N_{\mathrm{c}}=\frac{7758 A h \phi\left(1-S_{\mathrm{or}}-S_{\mathrm{wc}}\right)}{365 i_{\mathrm{s}} t_{\mathrm{c}}}$

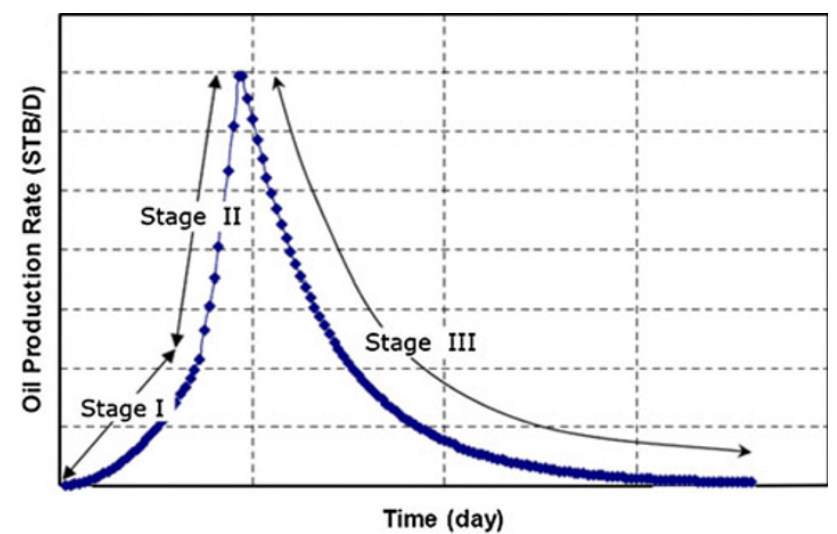

Fig. 1 Chandra and Mamora: three stages of oil production profile

$t_{\mathrm{c}}=\frac{t_{\mathrm{cD}} h_{\mathrm{t}}^{2} M_{1}^{2}}{35,040 K_{\mathrm{h}} M_{2}}$

Limit: $A_{\mathrm{cD}_{\max }} \geq V_{\mathrm{oD}} \geq 0$

$V_{\mathrm{pD}}=\left[\frac{V_{\mathrm{s}, \mathrm{inj}} \times 5.62}{43,560 A_{\mathrm{s}} h_{\mathrm{n}} \phi S_{\mathrm{g}}}\right]^{2}$

Limit: $0 \leq \mathrm{V}_{\mathrm{pD}} \leq 1.0$ and $V_{\mathrm{pD}}=1.0$ at $S_{\mathrm{g}}=0$.

\section{Modified volumetric model}

Steam is lighter than oil, therefore when steam is injected gravity segregation occurs and steam moves vertically upward. This process takes place so rapidly that the reservoir heating occurs mainly due to the vertical expansion of steam zone. Since steam zone thickness varies with time, a new vertical sweep efficiency (Eq. 13) term gets incorporated $\left(E_{\mathrm{SV}}\right)$ into the capture efficiency. This vertical sweep efficiency has a role when reservoir thickness is more than $200 \mathrm{ft}$. For reservoir thickness less than $200 \mathrm{ft}$, it is found that steam zone thickness is equal to sand zone thickness (Green and Willhite 1998). The calculation of average steam thickness is based on energy and mass balance over a thin slice of reservoir in the vertical cross section (Neuman 1985).

Capture efficiency $=A_{\mathrm{cD}} \times V_{\mathrm{oD}} \times V_{\mathrm{pD}} \times E_{\mathrm{sv}}$

where $E_{\mathrm{sv}}$ is assumed to be the ratio of steam zone thickness to that of net pay zone thickness:

$E_{\mathrm{sv}}=\frac{h_{\mathrm{st}}}{h_{\mathrm{t}}}=\frac{C_{\mathrm{w}} \Delta T_{\mathrm{s}}}{h_{\mathrm{fg}} h_{\mathrm{t}}}\left(\frac{\pi t K_{\mathrm{h}}}{M_{2}}\right)^{0.5}$

where, $\quad h_{\mathrm{st}}=\frac{V_{\mathrm{s}}}{A_{\mathrm{s}}}$

$A_{\mathrm{s}}=\left(\frac{h_{\mathrm{fg}} f_{\mathrm{s}} i_{\mathrm{s}}}{K_{\mathrm{h}} \Delta T_{\mathrm{s}}}\right)\left(\frac{K_{\mathrm{h}} t}{M_{2} \pi}\right)^{0.5}$ 
Table 1 Reservoir characteristic and operating conditions of Schoonebeek, San Ardo and Hamaca fields

\begin{tabular}{|c|c|c|c|}
\hline $\begin{array}{l}\text { Characteristics of reservoir and } \\
\text { operating conditions }\end{array}$ & Schoonebeek & $\begin{array}{l}\text { San } \\
\text { Ardo }\end{array}$ & Hamaca \\
\hline Effective pattern area, $A$ (acres) & 15 & 10 & 10 \\
\hline Porosity (fraction) & 0.3 & 0.345 & 0.3 \\
\hline Permeability (md) & $1,000-10,000$ & 6,922 & 12,000 \\
\hline Initial oil saturation (fraction) & 0.47 & 0.73 & 0.832 \\
\hline Residual oil saturation (fraction) & 0.25 & 0.15 & 0.15 \\
\hline Initial gas saturation (fraction) & 0.4 & 0 & 0 \\
\hline Initial oil viscosity (cp) & 180 at $100{ }^{\circ} \mathrm{F}$ & $\begin{array}{l}3,000 \text { at } \\
127^{\circ} \mathrm{F}\end{array}$ & $\begin{array}{l}25,000 \text { at } \\
125^{\circ} \mathrm{F}\end{array}$ \\
\hline Reservoir temperature $\left({ }^{\circ} \mathrm{F}\right)$ & 100 & 127 & 125 \\
\hline $\begin{array}{l}\text { Oil formation volume factor } \\
(\mathrm{STB} / \mathrm{B})\end{array}$ & 1.01 & 1.01 & 1.01 \\
\hline $\begin{array}{l}\text { Thermal conductivity of } \\
\text { formation }\left[\mathrm{BTU} /\left(\mathrm{ft}-\mathrm{hr}-^{\circ} \mathrm{F}\right)\right]\end{array}$ & 1.2 & 1 & 1 \\
\hline Rock density (lb/cu ft) & 174 & 174 & 174 \\
\hline $\begin{array}{l}\text { Heat capacity of rock (BTU/ } \\
\left(\mathrm{lbm}-{ }^{\circ} \mathrm{F}\right)\end{array}$ & 0.21 & 0.21 & 0.21 \\
\hline Water density (lb/cu ft) & 62.428 & 62.428 & 62.428 \\
\hline Oil density (lb/cu ft) & 56.444 & 61.550 & 62.864 \\
\hline $\begin{array}{l}\text { Heat capacity of water (Btu/lbm- } \\
\left.{ }^{\circ} \mathrm{F}\right)\end{array}$ & 0.96 & 0.96 & 0.96 \\
\hline $\begin{array}{l}\text { Heat capacity of oil (Btu/lbm- } \\
\left.{ }^{\circ} \mathrm{F}\right)\end{array}$ & 0.5 & 0.5 & 0.5 \\
\hline Total thickness (ft) & 83 & 115 & 100 \\
\hline Net thickness (ft) & 83 & 115 & 100 \\
\hline $\begin{array}{l}\text { Volumetric heat capacity of rock } \\
\left.\left(\text { BTU/(cu ft- }{ }^{\circ} \mathrm{F}\right)\right)\end{array}$ & 35 & 35.2 & 35.2 \\
\hline $\begin{array}{l}\text { Injection rate, cold water } \\
\text { equivalent (bbl/day) }\end{array}$ & 1,250 & 1,600 & 1,600 \\
\hline Saturated steam pressure (psia) & 600 & 600 & 600 \\
\hline Steam quality (fraction) & 0.7 & 0.8 & 0.8 \\
\hline Injection temperature $\left({ }^{\circ} \mathrm{F}\right)$ & 350 & 582.3 & 582.3 \\
\hline $\begin{array}{l}\text { Oil viscosity at steam } \\
\text { temperature }(\mathrm{cp})\end{array}$ & 3.5 & 3.5 & 3.5 \\
\hline $\begin{array}{l}\text { Volumetric heat capacity: over } \\
\text { and under }\left(\mathrm{BTU} /\left(\mathrm{cu} \mathrm{ft}-{ }^{\circ} \mathrm{F}\right)\right.\end{array}$ & 42 & 60 & 60 \\
\hline Total day of calculations (days) & 2,190 & 6,900 & 6,900 \\
\hline
\end{tabular}

$V_{\mathrm{s}}=\frac{C_{\mathrm{w}} Q_{\mathrm{s}} t}{M_{2}\left(h_{\mathrm{fg}}+C_{\mathrm{w}} \Delta T_{\mathrm{s}}\right)}$.

Jones and Chandra and Mamora both calculated dimensionless steam zone size in their analysis. In the calculation of $A_{\mathrm{cD}}$, they both took Marx and Langenheim (frontal advance model) (Marx and Langenheim 1959) as a reference to calculate steam zone size, $A_{\mathrm{s}}$.

$A_{\mathrm{s}}=\frac{Q_{\mathrm{inj}} h_{\mathrm{n}} M_{1}}{4 K_{\mathrm{h}}\left(t_{\mathrm{s}}-t_{\mathrm{f}}\right) M_{2} \times 43,560}\left(e^{t_{\mathrm{D}}} \operatorname{erfc} \sqrt{t_{\mathrm{D}}}+\sqrt{t_{\mathrm{D}} / \pi-1}\right)$.
But in the reservoir, due to gravity segregation, steam zone size differs from that calculated by the Marx and Langenheim model. Neuman developed a new model to calculate steam zone size for the gravity override model (Neuman 1975). According to Neuman model, steam zone size (Eq. 18) is given by:

$A_{\mathrm{s}}=\left(\frac{Q_{\mathrm{s}}}{K_{\mathrm{h}} \Delta T_{\mathrm{s}}}\right)\left(\frac{h_{\mathrm{fg}}}{h_{\mathrm{fg}}+C_{\mathrm{w}} \Delta T_{\mathrm{s}}}\right)\left(\frac{D t}{\pi}\right)^{0.5}$

where $Q_{\mathrm{s}}=m_{\mathrm{s}} f_{\mathrm{s}}\left(h_{\mathrm{fg}}+C_{\mathrm{w}} \Delta T_{\mathrm{s}}\right)$.

$A_{\mathrm{s}}=\left(\frac{h_{\mathrm{fg}} f_{\mathrm{s}} i_{\mathrm{s}}}{K_{\mathrm{h}} \Delta T_{\mathrm{s}}}\right)\left(\frac{K_{\mathrm{h}} t}{M_{2} \pi}\right)^{0.5}\left(\frac{350 \times \sqrt{24}}{43,560 \times 24}\right)$.

\section{Case study: field location and setting}

\section{Case 1: Schoonebeek oil field}

The Schoonebeek oil field is situated in the eastern part of the Netherlands at the German border. The oil is produced from the Bentheim barrier sands of Neocom/Valanginian age. A completely sealing fault divides the accumulation into two separate reservoirs. The southwestern part produces by solution-gas drive and the remainder of the field by edge-water drive. In the greater part of the field, the reservoir consists of a single, unconsolidated sand body. Schoonebeek pilot project is an inverted five-spot pattern. Due to steam drive, oil recovery from this field increased from 5 to $38 \%$.

\section{Case 2: San Ardo field}

The San Ardo is a large oil field in Monterey County, California, in the USA. It is in the upper Salinas Valley and has an anticline structure. The productive units are the Aurignac sands, which are a portion of the huge Monterey Formation. Above the Aurignac sands are the thinner but also productive Lombardi sands. All of the productive units are of Miocene age with the underlying basement rocks dated to the Jurassic period

\section{Case 3: Hamaca field}

The Hamaca field is located in Venezuela's Orinoco heavy oil belt and is a huge stratigraphic trap on the southern flank of the Oriente basin. The Hamaca concession area, which covers 160,000 acres, contains oil trapped in shallow fluvial-deltaic reservoirs of the Oficina Formation (Miocene age). Sandstone reservoirs of the Oficina Formation at 
Fig. 2 Oil production profile (barrels of oil produced per day vs. days of production) of the Schoonebeek field. a Jeff Jones Model, b Modified volumetric model

Fig. 3 Oil production profile (barrels of oil produced per day vs. days of production) of the San Ardo field. a Jeff Jones Model, b Modified volumetric model

Fig. 4 Oil production profile (barrels of oil produced per day vs. days of production) of the Hamaca field. a Jeff Jones Model, b Modified volumetric model

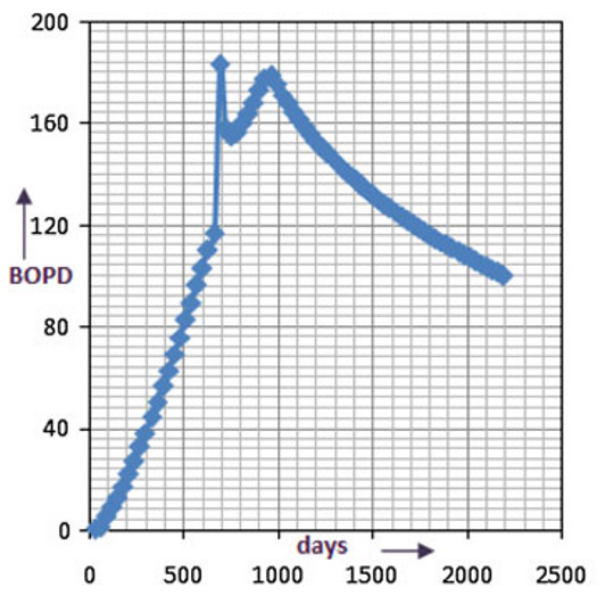

(a)

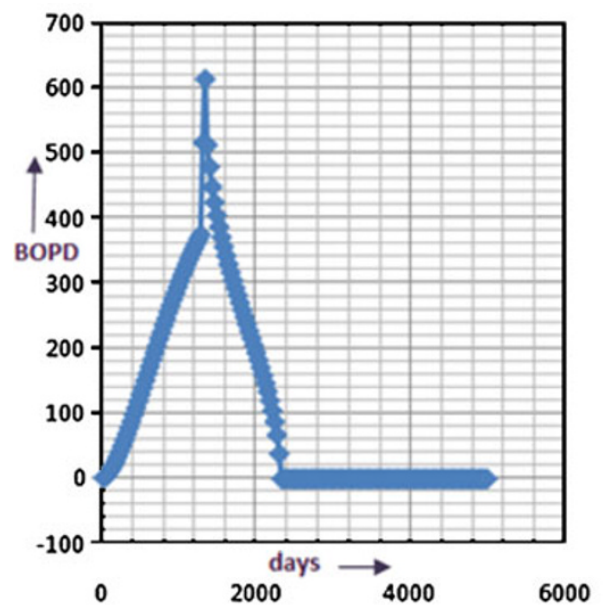

(a)

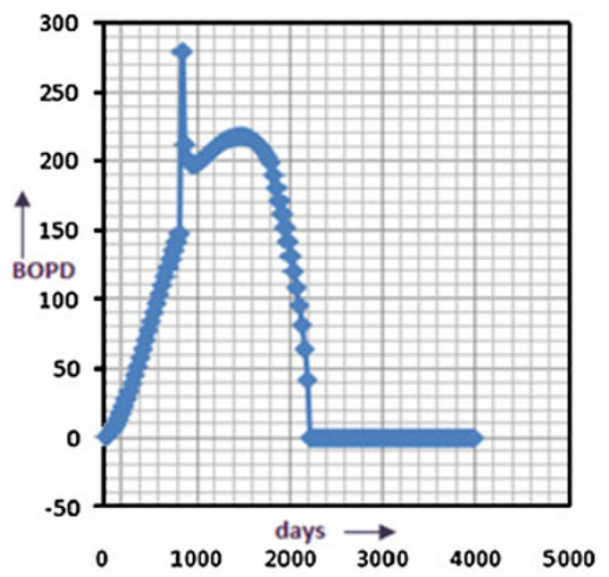

(a)

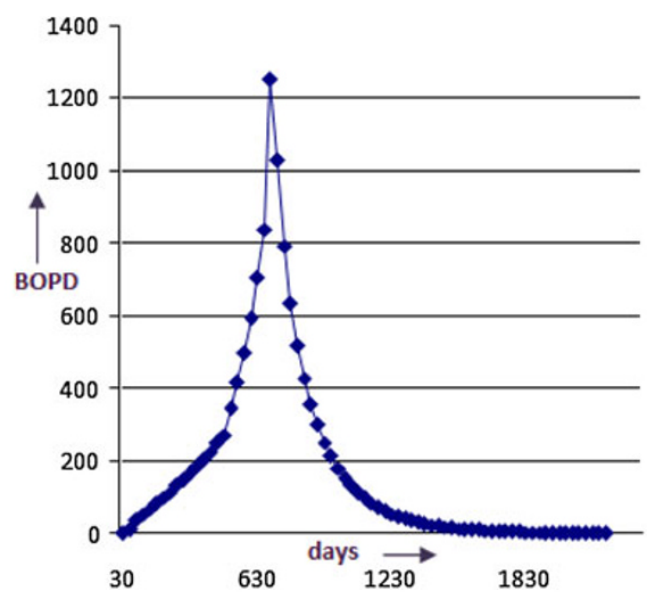

(b)

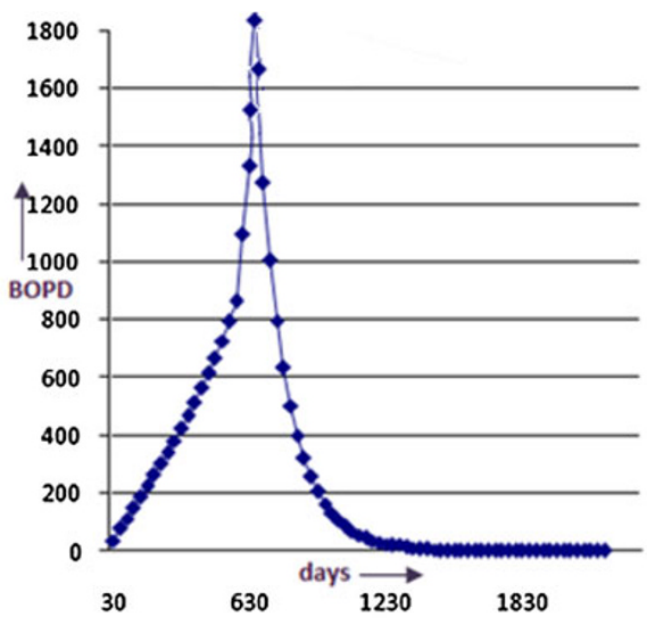

(b)

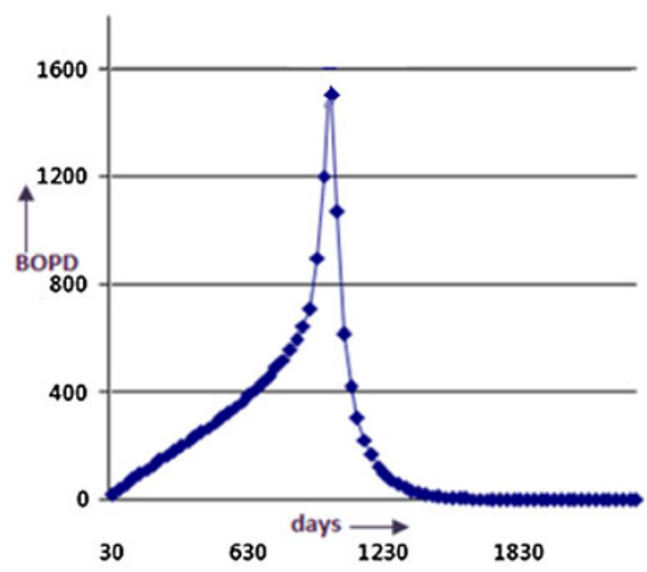

(b) 
Table 2 Comparison of maximum oil production rate as predicted by different models

\begin{tabular}{lccc}
\hline $\begin{array}{l}\text { Calculated oil } \\
\text { peak rate }\end{array}$ & $\begin{array}{l}\text { Schoonebeek } \\
\text { field (bbl/day) }\end{array}$ & $\begin{array}{l}\text { San Ardo field } \\
\text { (bbl/day) }\end{array}$ & $\begin{array}{l}\text { Hamaca } \\
\text { field } \\
\text { (bbl/day) }\end{array}$ \\
\hline $\begin{array}{l}\text { Jeff Jones model } \\
\begin{array}{l}\text { Suandy Chandra } \\
\text { model }\end{array}\end{array}$ & 181 & 620 & 280 \\
$\begin{array}{l}\text { Modified volumetric } \\
\text { model }\end{array}$ & 1,250 & 1,600 & 1,600 \\
\begin{tabular}{l} 
Actual field value \\
\hline
\end{tabular} & 1,317 & 1,880 & 1,480 \\
\hline
\end{tabular}

Table 3 Comparison of Cumulative oil production as predicted by different models

\begin{tabular}{llrl}
\hline $\begin{array}{l}\text { Cumulative oil } \\
\text { production }\end{array}$ & $\begin{array}{l}\text { Schoonebeek } \\
\text { field (bbl) }\end{array}$ & $\begin{array}{l}\text { San Ardo } \\
\text { field (bbl) }\end{array}$ & $\begin{array}{l}\text { Hamaca } \\
\text { field (bbl) }\end{array}$ \\
\hline Jeff Jones model & 243,828 & 508,826 & 312,555 \\
$\begin{array}{l}\text { Suandy Chandra model } \\
\begin{array}{l}\text { Modified volumetric } \\
\text { model }\end{array}\end{array}$ & 633,758 & $1,022,254$ & 784,155 \\
Actual field value & 444,069 & 540,639 & 491,989 \\
\hline
\end{tabular}

Table 4 Comparison of maximum recovery as predicted by different models

\begin{tabular}{llll}
\hline $\begin{array}{l}\text { Oil recovery } \\
\text { (fraction) }\end{array}$ & $\begin{array}{l}\text { Schoonebeek } \\
\text { field }(\%)\end{array}$ & $\begin{array}{l}\text { San Ardo } \\
\text { field }(\%)\end{array}$ & $\begin{array}{l}\text { Hamaca field } \\
(\%)\end{array}$ \\
\hline $\begin{array}{l}\text { Jeff Jones model } \\
\text { Suandy Chandra } \\
\text { model }\end{array}$ & 18 & 22.89 & 16 \\
$\begin{array}{c}\text { Modified } \\
\text { volumetric model }\end{array}$ & 28 & 43 & 40 \\
$\begin{array}{c}\text { Actual field value } \\
\text { A }\end{array}$ & 33 & 24.3 & 25 \\
\hline
\end{tabular}

Hamaca were generally deposited in a bedload-dominated, fluvial-deltaic environment. Hamaca crude is considered "foamy" and is generally saturated with gas at reservoir conditions.

\section{Reservoir characteristic and operating condition}

At maximum production rate, the vertical sweep efficiency is unity because the steam zone thickness is equal to the net pay zone thickness. The various reservoir parameters and characteristics data which have been used to predict the performance of steam flooding are shown in Table 1.

\section{Results and discussion}

The results obtained using the modified volumetric model agrees with the actual field data in comparison to those obtained from Jeff Jones model and Chandra and Mamora model. Three fields were analyzed for this using macro programming in Excel. The barrels of oil produced per day were plotted against the days of production using the Jeff Jones model as shown in Figs. 2a, 3a, 4a. In contrast to this, the same was plotted using the modified volumetric model as shown in Figs. 2b, 3b, 4b. The graphs clearly show the consistency and accuracy of the new model. Moreover, to further prove the validity of this model, the results of the prediction of the model were compared with that of actual field data. The oil peak rate calculated by the modified volumetric model is close to the actual data, as compared to that calculated using Jeff Jones model and Chandra and Mamora model as shown in Table 2. Chandra and Mamora model's prediction of cumulative oil production data is very large as compared to the actual field data as shown in Table 3. In this table, it can be clearly seen that the new model gives the best prediction. Similarly, maximum recovery prediction for the three fields shows that modified the volumetric prediction is better off than the other widely accepted models as shown in Table 4.

\section{Conclusion}

1. Analytical models (volumetric) are used to predict steam flood performance (preliminary forecasting purposes and sensitivity studies) because these require few data, give quick results and provide better insight, than simulation, into the physics of the thermal process.

2. The most widely used analytical model given by Jeff Jones and then modified by Chandra and Mamora has the limitation of the frontal advance model, and hence give unsatisfactory prediction of oil production.

3. The new modified volumetric model, as presented in this paper, removes the above limitation by considering gravity segregation in the development of the model.

4. Results based on the modified model agree with field results for three different sets of reservoir and fluid properties: Schoonebeek field, San Ardo field and Hamaca field.

5. Engineers will find the modified model an improved and useful tool for prediction of steam flood production performance. In this study, it has been proved that the new modified model can predict more accurately than the earlier existing models. 
6. Engineers can predict the economic feasibility and optimum injection rate with the new volumetric model. Performance prediction is essential to provide information for proper execution of each of these development phases. Therefore, this model is very useful for engineers in the decision-making process.

Open Access This article is distributed under the terms of the Creative Commons Attribution License which permits any use, distribution, and reproduction in any medium, provided the original author(s) and the source are credited.

\section{References}

Alajmi AF (2011) Modeling of oil bank formation during steam flood. (SPE 142618), SPE Middle East Oil and Gas Show and Conference held in Manama, Bahrain, 25-28 Sept 2011

Chandra S, Mamora DD (2005) Improved steam flood analytical model. In: Paper (SPE 97870), SPE-PE/CIM-CHAO International Thermal operations and heavy oil symposium, Calgary, 1-3 Nov
Green DW, Willhite GP (1998) Enhanced oil recovery. Society of Petroleum Engineers, Richardson, pp 330-370

Jones J (1981) Steam drive model for hand-held programmable calculators. J Petroleum Technol 33(9):1583-1598

Lookeren JV (1977) Calculation methods for linear and radial steam flow in oil reservoirs. In: SPE 6788, SPE 52nd annual technical conference and exhibition, Denver, 9-12 Oct

Marx JW, Langenheim RH (1959) Reservoir heating by hot fluid injection. Trans AIME 216:312-314

Myhill NA, Stegemeier GL (1978) Steam-drive correlation and prediction. J Petroleum Technol 30:173-182

Neuman CH (1975) A mathematical model of the steam drive process-applications. In: SPE 4757, SPE 50th annual technical conference and exhibition, Dallas, 28 Sept -1 Oct

Neuman CH (1985) A Gravity override model of steam drive. J Petroleum Technol 37(1):163-169

Prats M (1982) Thermal recovery, SPE monograph, vol 7. Society of Petroleum Engineers of AIME, Dallas

Volek CW, Pryor JA (1972) Steam distillation drive-Brea Field, California. J Petroleum Technol 24(8):899-906

Willman BT et al (1961) Laboratory studies of oil recovery by steam injection. JPT (July) 681-690, Trans-AIME, 222 